\title{
PENERAPAN TELENURSING DALAM PELAYANAN KESEHATAN : LITERATURE REVIEW
}

\author{
Rizka Fadhila $^{1,}$, Tuti Afriani ${ }^{2}$ \\ ${ }^{1}$ Mahasiswa Magister Keperawatan Fakultas Ilmu Keperawatan Universitas Indonesia \\ ${ }^{2}$ Departemen DKKD Fakultas Ilmu Keperawatan Universitas Indonesia \\ Depok Jawa Barat Indonesia \\ Telp : 081266569668 \\ Email : chekila.rizka@gmail.com
}

\begin{abstract}
The development of information and communication technology has a big effect on the field of health, especially the field of nursing. Nurses are required to take advantage of technological developments one of them through telenursing service (telenursing). Telenursing is a component telehealth that occurs when nurses meet the health needs of clients using information communication technologies and web-based systems. Technologies that can be used in telenursing vary widely, including: telephones, personal digital assistants, smartphones, facsimile machines, tablets, computers, internet, video and audio conferencing, teleradiology dan computer information systems. The purpose of this paper is to find out the application of telenursing in health services. Writing method used is literature study which analyzed from several journals related to the topic taken. Journals are investigated through Proquest, Ebsco, Science Direct, and Clinical Key which are then selected according to the topics to be discussed. The results of the analysis indicate that the application of telenursing has a positive impact on public health. Telenursing allows to be applied in Indonesia in an effort to improve the quality of health service.
\end{abstract}

Key word : information technology, telenursing, nurse

\begin{abstract}
Abstrak
Perkembangan teknologi informasi dan komunikasi berpengaruh besar terhadap bidang kesehatan khususnya bidang keperawatan. Perawat dituntut untuk memanfaatkan perkembangan teknologi salah satunya melalui pelayanan keperawatan jarak jauh (telenursing). Telenursing adalah komponen telehealth yang terjadi ketika perawat memenuhi kebutuhan dasar klien dengan menggunakan teknologi informasi komunikasi dan sistem berbasis web. Teknologi yang dapat digunakan dalam telenursing sangat bervariasi, meliputi: telepon, personal digital assistants, smartphone, mesin faksimili, tablet, computer, internet, video dan audio conferencing, teleradiologi dan system informasi komputer. Tujuan penulisan ini adalah untuk mengetahui penerapan telenursing dalam pelayanan kesehatan. Metode penulisan yang digunakan adalah studi literatur yang dianalisis dari beberapa jurnal. yang terkait dengan topik yang diambil. Jurnal ditelurusi melalui Proquest, Ebsco, Science Direct, dan Clinical Key yang kemudian diseleksi sesuai dengan topik yang akan dibahas. Hasil analisis menunjukkan bahwa penerapan telenursing mempunyai dampak positif terhadap kesehatan masyarakat. Telenursing memungkinkan untuk diterapkan di Indonesia dalam upaya meningkatkan kualitas pelayanan kesehatan.
\end{abstract}

Kata kunci : teknologi informasi, telenursing, perawat

\section{PENDAHULUAN}

Selama beberapa dekade terakhir, teknologi informasi dan komunikasi dalam perawatan kesehatan telah menjadi prioritas politik di seluruh dunia (WHO, 2015). Pengembangan teknologi informasi dan komunikasi mempunyai dampak yang signifikan dalam setiap bagian kehidupan seharihari dan telah mendukung aplikasi teknologi informasi dan komunikasi dalam bidang kesehatan (Schlachta et al, 2007). Dengan diperkenalkannya teknologi informasi dalam bidang perawatan kesehatan sehingga muncul metode baru dalam memberikan asuhan 
keperawatan yang dikenal dikenal dengan telenursing (Asiri et al, 2006).

Perawat semakin dituntut untuk profesional dan mengedepankan perkembangan teknologi, termasuk dalam pemanfaatan teknologi informasi dibidang pelayanan keperawatan, dimana pasien yang membutuhkan asuhan keperawatan dapat berasal dari berbagai kalangan dalam dunia maya yang dapat diakses melalui pelayanan keperawatan jarak jauh dimanapun ia berada (Schlachta et al, 2007).

Telenursing adalah penggunaan teknologi untuk memberikan asuhan keperawatan dan praktek keperawatan jarak jauh kepada pasien yang bertujuan untuk memperbaiki perawatan kesehatan (Asiri et al, 2016). Hal ini merupakan bentuk komunikasi dan teknologi informasi yang bergantung kepada faktor manusia, keuangan dan teknologi itu sendiri (Jönsson \& Willman, 2009)

Pertumbuhan populasi manusia yang semakin tinggi menyebabkan terjadi peningkatan kebutuhan akan perawatan kesehatan dan kurangnya tenaga perawat menjadi masalah penting untuk menemukan cara-cara dimana teknologi informasi dan komunikasi dapat digunakan untuk memenuhi kebutuhan perawatan kesehatan di dunia (Schlachta et al, 2007).

Dengan semakin berkembangnya penggunaan internet dan diikuti pula dengan perkembangan dalam dunia kesehatan dan keperawatan sehingga telemedicine, telehealth dan telenursing menjadi alternatif dalam memberikan pelayanan kesehatan dan keperawatan (McLean et al., 2013). Penerapan telenursing dalam memberikan pelayanan keperawatan akan meningkatkan kepuasan klien dan peningkatan parstisipasi aktif keluarga (Souza, 2015). Telenursing dapat membantu menyelesaikan kekurangan perawat, menurunkan jarak, waktu kunjungan dan menjaga pasien yang sudah keluar dari rumah sakit (Asiri et al, 2016). Layanan kesehatan khususnya keperawatan jarak jauh dengan menggunakan media teknologi informatika memberikan kemudahan bagi masyarakat (McLean et al., 2013)

Masyarakat atau pasien tidak perlu datang ke rumah sakit, dokter atau perawat untuk mendapatkan layanan kesehatan. Waktu yang diperlukan untuk layanan kesehatan juga semakin pendek. Pasien dari dirumah dapat melakukan kontak melalui internet atau telepon video untuk mendapatkan informasi kesehatan, perawatan dan bahkan sampai pengobatan. Pada kesempatan ini penulis mencoba menggali lebih dalam mengenai informasi dan hasil-hasil riset seputar telenursing tersebut.

\section{METODE}

Metode penulisan yang digunakan yaitu studi literatur yang ditelaah dari beberapa jurnal terkait dengan topik yang diambil yaitu tentang penerapan telenursing dalam pelayanan kesehatan. Jurnal ditelurusi melalui Proquest, Ebsco, Science Direct, dan Clinical Key kemudian diseleksi sesuai dengan topik yang akan dibahas. Kata kunci pencarian yaitu teknologi informasi telenursing dan perawat.

\section{HASIL DAN PEMBAHASAN}

Menurut American Nurse Association (ANA), telenursing adalah bagian dari telehealth yang fokusnya pada praktek keperawatan (Asiri, 2016) yang terjadi ketika perawat memenuhi kebutuhan dasar klien dengan menggunakan teknologi informasi komunikasi dan sistem berbasis web (Schlachta et al, 2007). Telenursing juga didefinisikan sebagai suatu proses pemberian, pengaturan dan koordinasi asuhan serta 
pemberian layanan kesehatan melalui teknologi informasi dan komunikasi (Scotia, 2017).

Teknologi yang dapat digunakan dalam telenursing sangat bervariasi meliputi: telepon, personal digital assistants, smartphone, mesin faksimili, tablet, komputer, internet, video dan audio conferencing dan system informasi komputer (Scotia, 2017). Walaupun terdapat sedikit perubahan dalam pemberian asuhan keperawatan melalui telenursing tetapi hal tersebut tidak merubah prinsip pemberian asuhan keperawatan secara fundamental (Asiri, 2016).

Seorang perawat yang melakukan telenursing tetap menggunakan proses keperawatan untuk mengkaji, merencanakan, mengimplementasikan, mengevaluasi dan mendokumentasikan asuhan keperawatan (Sanderson, 2018). Telenursing juga melibatkan proses pemberian pendidikan kesehatan kepada klien, serta adanya sistem rujukan. Selain itu telenursing juga tetap mengharuskan adanya hubungan terapeutik antara perawat dan klien, dalam telenursing hubungan tersebut dapat terbina melalui penggunaan telepon, internet atau alat komunikasi yang lainnya (Scotia, 2017).

Prinsip yang harus dilakukan dalam menerapkan telenursing antara lain meningkatkan kualitas pelayanan kesehatan, meningkatkan akses terhadap pelayanan kesehatan, mendefinisikan peran dan tanggung jawab secara fleksibel dan mengurangi penyampaian informasi yang tidak perlu serta melindungi privasi dan keamanan informasi yang berkaitan dengan klien (Scotia, 2017).

Untuk menjadi telenurse, seorang perawat harus memiliki sikap positif, pikiran terbuka, pengetahuan dan kemampuan teknologi. Perawat harus mampu menilai kebutuhan rawat inap klien dan mampu untuk mengubah rencana perawatan (Souza, 2015). Tidak ada pelayanan yang bisa disampaikan secara efektif tanpa keterampilan komunikasi yang kompeten. Telekomunikasi membutuhkan penggunaan teknologi yang sering sehingga perawat harus ramah teknologi. Klien yang menerima pelayanan hanya bisa diselamatkan dengan informasi dan perawatan berbasis bukti sehingga perawat harus terus menerus mengupdate pengetahuannya. Mereka harus memiliki keterampilan untuk memberikan layanan keperawatan yang kompeten melalui teknologi (Ghai \& Kalyan, 2013).

Menurut Hakimnia et al (2014) cara berkomunikasi dengan masing-masing pasien itu berbeda. Komunikasi antara telenurses dengan penelepon harus dibuat setara sehingga cocok untuk semua penelepon.

Menurut Ghai \& Kalyan (2013) manfaat telenursing bagi perawat yaitu meningkatkan penghasilan, jam kerja yang fleksibel, menurunkan biaya perjalanan perawatan karena perawat memberikan pelayanan dari rumah, pelayanan yang diberikan hanya dari jarak jauh, meningkatkan kepuasan kerja dan kesempatan untuk mengembangkan keterampilan, menjadi pilihan pekerjaan baru, bisa berbagi data serta respon waktu yang cepat. Sedangkan keuntungan telenursing bagi pasien adalah penduduk yang tinggal di daerah terpencil dapat memperoleh perawatan kesehatan jika mereka memiliki fasilitas internet di telepon atau komputer mereka, dan akses yang mudah untuk mendapatkan pelayanan keperawatan yang berkualitas tinggi dengan biaya yang rendah karena mereka tidak harus melakukan perjalanan ke lokasi yang jauh. 
Masalah yang berhubungan dengan telenursing yaitu kesulitan dalam menggunakan teknologi karena kurangnya petunjuk, kurangnya pendidikan, dan kurangnya bantuan dan dukungan bagi perawat dan pasien. Kita bisa menghadapi kegagalan teknologi, ancaman terhadap keselamatan pasien dan malpraktek (George, 2009). Untuk memastikan percakapan klien dengan perawat adalah masalah etika yang besar. Tidak menghargai dialog dengan perawat wanita dan kesulitan yang dihadapi saat berbicara dengan pasien pria adalah tantangan lain. Memastikan kerahasian dan inform consent juga menjadi masalah dalam telenursing (Ghai \& Kalyan, 2013).

Perawat yang melakukan telenursing harus perawat yang memiliki lisensi yang valid dan terkini. Kategori pelayanan kesehatan yang bisa diberikan melalui telenursing yaitu preventif misalnya pencegahan efek berbahaya dari penyalahgunaan obatobatan, alkohol, layanan gizi, dan survey kesehatan; promotif meliputi pendidikan kesehatan terkait latihan fisik dan kebiasaan diet sehat; kuratif meliputi layanan yang berhubungan dengan pengobatan penyakit misalnya pemeriksaan dan pemberian resep obat, rehabilitatif meliputi layanan tindak lanjut setelah dirawat di rumah sakit dengan penyakit kronis, operasi dll; dan pelayanan khusus meliputi fisioterapi, tes laboratorium, layanan okupasional, layanan kecanduan dan layanan rujukan baik untuk pribadi atau instansi kesehatan atau sesuai dengan keinginan pasien (Hederbergh, 2007; Sharma, 2014).

Salah satu contoh penerapan telenursing dalam pelayanan kuratif yaitu penggunakan teknologi telepon video dalam mengontrol gula darah pasien dengan penyakit diabetes mellitus (Kotsani, 2018). Hal ini dapat memfasilitasi komunikasi antara pasien dengan perawat, menyediakan kehidupan yang nyaman bagi pasien, dan memberikan pasien kesempatan untuk mempertahankan pendidikan kesehatan mereka secara efektif dan tanpa interupsi (Ghai \& Kalyan, 2013). Dengan telenursing pasien bisa berobat dirumah tanpa harus hadir di pusat kesehatan. Teknologi telepon video memungkinkan komunikasi tatap muka dengan mudah antara pasien diabetes mellitus dengan petugas kesehatan, memantau kadar gula darah dan memberikan umpan balik, serta memberikan motivasi kepada pasien (Kotsani, 2018; Tavsanli, Karadakovan, \& Saygili, 2013).

Di negara maju aplikasi telenursing tersedia di rumah, pusat telemedicine berbasis rumah sakit, rumah sakit dan pusat rehabilitasi. Berbeda dengan negara berkembang yang mana potensi telenursing belum diaplikasikan secara maksimal. Negara yang menerapkan telenursing akan memiliki manfaat yang berbeda terutama untuk negara maju dan negara berkembang. Misalnya dalam penggunaan teknologi seluler seperti smartphone dan tablet, tidak mungkin mereka yang kurang mampu akan memiliki akses teknologi seperti itu (Sharma, 2014).

Dalam penelitian yang berjudul "Nursing students perspectives on telenursing in patient care after simulation" dikatakan bahwa teknologi informasi dan komunikasi dalam perawatan kesehatan berkembang dengan pesat sehingga perawat mulai meninggalkan cara tradisional dalam memberikan asuhan keperawatan. Mahasiswa keperawatan memandang bahwa telenursing sangat berorientasi kemasa depan dan mereka berpendapat bahwa pendidikan keperawatan harus mempersiapkan mahasiswa yang 
mampu untuk melakukan telenursing (Reierson, Solli, \& Bjørk, 2015).

Hasil analisis dari jurnal yang berbeda dikatakan bahwa implementasi telenursing merupakan kebutuhan nasional. Generasi sekarang dalam hal ini mahasiswa keperawatan terlihat sangat ahli dalam bidang informatika dan penggunaan teknologi seperti komputer, email, dll sehingga mereka lebih siap untuk dapat memberikan pelayanan keperawatan berupa telenursing. Mahasiswa keperawatan memiliki sikap positif terhadap penggunaan telenursing di masa depan (Glinkowski, Pawlowska, \& Kozlowska, 2013).

Pemanfaatan teknologi telenursing mempunyai banyak manfaat dan keuntungan bagi berbagai pihak diantaranya pasien, petugas kesehatan dan pemerintah. Aspek kemudahan dan peningkatan jangkauan serta pengurangan biaya menjadi keuntungan yang bisa terlihat secara langsung. Dengan adanya kontribusi telenursing dalam pelayanan keperawatan di rumah atau homecare, akan banyak sekali manfaat yang dapat dirasakan oleh pasien dan keluarga, perawat, instansi pelayanan kesehatan dan termasuk juga pemerintah. Namun demikian untuk bisa mengaplikasikan telenursing dalam bidang keperawatan banyak sekali tantangan dan hambatannya seperti faktor biaya, sumberdaya manusia, kebijakan dan perilaku (Sudaryanto \& Purwanti, 2008)

Dalam proses komunikasi jarak jauh (telenursing) terdapat hambatan pada semua elemen yaitu pengirim pesan, penerima pesan dan pesan itu sendiri. Tantangan utama yang dihadapi dalam telenursing yaitu terjadinya komunikasi yang tidak memadai tentang kondisi klinis pasien sehingga menyebabkan terjadinya kesalahan klinis, keterbatasan sistem pendukung komputer mengenai komunikasi, kurangnya referensi visual saat berkomunikasi antara perawat dengan pasien terutama komunikasi tanpa video, kesulitan dalam memahami komunikasi nonverbal khusunya bila dilakukan menggunakan telepon. Dalam interaksi dengan video, sumber visual merupakan mekanisme kompensasi jarak, memberi rasa kedekatan, integrasi, perlindungan, dan keamanan untuk mengungkapkan kebutuhan, harapan dan perasaan. Meskipun teknik ini menggunakan sumber daya yang berbeda untuk mengatasi hambatan waktu dan jarak, untuk pelaksanaan perawatan yang tepat, perawat harus menerima pelatihan khusus untuk mengembangkan keterampilan dan kemampuan berkomunikasi (I et al., 2016)

Penelitian yang dilakukan Sharma (2014) di India mengatakan latar belakang munculnya telenursing adalah karena status India merupakan negara berkembang yang mempunyai tantangan untuk memenuhi kebutuhan kesehatan dari populasi masyarakat yang sangat besar. Padahal mereka memiliki berbagai lembaga kesehatan tetapi belum memadai untuk memberikan pelayanan kesehatan. Dalam menghadapi realita seperti itu telenursing dianggap mampu untuk memperbaiki keadaan. Dimana masyarakat bisa mengakses perawatan kesehatan dengan cara yang mudah dan biaya yang efektif sehingga dapat meningkatkan kesehatan dan kesejahteraan masyarakat. Dengan telenursing perawat bisa memperluas jangkauan, dapat memberikan perawatan kesehatan kapan dan dimana pasien membutuhkannya bahkan dirumah mereka.

Kualitas perawatan dari telenursing ditentukan oleh pelatihan, keterampilan, pengetahuan, sikap, dan perilaku 
masing-masing indidvidu. Dengan penerapan telenursing seharusnya kapasitas untuk mengobati meningkat sehingga mengurangi kebutuhan konsumen untuk mencari pelayanan keperawatan yang tidak ilmiah dan praktek swasta yang mahal. Perubahan besar ini akan membuat penggunaan sistem kesehatan masyarakat lebih efektif dan efisien untuk kepentingan konsumen kesehatan (Sharma, 2014).

Penelitian yang dilakukan oleh Remelet et al (2014) tentang dampak pelayanan telenursing terhadap kepuasan keluarga dan hasil kesehatan anak dengan penyakit rematik inflamasi menerangkan bahwa penyakit rematik inflamasi memiliki dampak yang siginifikan terhadap kualitas hidup anak dan fungsi keluarganya. Kontrol penyakit dan penanganan gejala penting untuk meminimalkan kecacatan dan rasa sakit. Dalam hal ini perawat berperan penting untuk mendukung tim medis dalam mengontrol penyakit, kebutuhan dalam perubahan pengobatan, memberikan dukungan dan saran serta mengidentifikasi pelayanan terbaik untuk mencapai hasil yang optimal bagi pasien dan keluarga melalui telenursing. Dalam hal ini telenursing dirancang untuk mendukung orang tua dan anak-anak dalam menghadapi penyakit rematik inflamasi. Intervensi telenursing yang dilakukan menawarkan dukungan bagi perawat dalam menentukan cara saling berkomunikasi dengan pasien untuk mencapai hasil kesehatan yang optimal. Tiga landasan konseptualnya yaitu kekeluargaan, interaksi profesional dan hasil kesehatan. Intervensi telenursing ini dirancang untuk menjamin kesinambungan perawatan anak-anak dan keluarga mereka melalui telepon dan membantu keluarga memenuhi kebutuhannya untuk mendapatkan informasi kesehatan, dukungan afektif dan bantuan dalam mengambil keputusan.

Penerapan telenursing di Indonesia telah dilakukan namun belum berjalan dengan baik karena keterbatasan sumber daya, sarana dan prasarana serta belum maksimalnya dukungan dari pemerintah. Padahal jika dilihat dari kemajuan teknologi seperti dalam penggunaan internet, komputer dan smartphone, telenursing sangat berpotensi untuk dikembangkan secara maksimal dalam upaya untuk memenuhi kebutuhan pelayanan kesehatan yang terus meningkat. Untuk mensiasati keterbatasan pelaksanaan telenursing bisa dimulai dengan peralatan yang sederhana seperti telepon rumah dan smartphone yang sudah banyak dimiliki oleh masyarakat tetapi masih belum banyak dimanfaatkan untuk kepentingan pelayanan kesehatan/keperawatan.

Penerapan telenursing memiliki potensi yang besar untuk meningkatkan akses keperawatan, menekan biaya dan meningkatkan hasil akhir dari perawatan kesehatan. Namun peningkatan penggunaan teknologi akan mempengaruhi hubungan perawat dan klien dengan kualitas perawatan. Hubungan perawat dan klien tidak dapat digantikan dengan teknologi. Tetapi pemberian asuhan keperawatan tanpa sentuhan langsung dari tangan perawat atau menggunakan telenursing dapat dikatakan sebagai asuhan keperawatan yang legal, karena dalam sistem telenursing perawat menggunakan pengetahuan, keterampilan, pertimbangan dan pemikiran kritis yang tidak bisa dipisahkan dari ilmu keperawatan, yang meliputi penggunaan ilmu keperawatan, pemikiran kritis, dan pengambilan keputusan.

\section{KESIMPULAN}


Penerapan telenursing memberikan dampak positif terhadap berbagai pihak seperti pasien, perawat dan pemerintah. Namun hal ini harus didukung oleh keterampilan dan pengetahuan perawat itu sendiri. Perawat harus memiliki pengetahuan tentang komunikasi yang cukup dalam penerapan telenursing karena dalam pelaksanaannya perawat akan dihadapkan dengan berbagai tipe pasien yang hanya kita kenal melalui dunia maya atau komunikasi jarak jauh. Komunikasi yang baik akan berdampak pada perasaan sehingga setiap perkataan akan mudah untuk didengar dan dipahami. Dengan demikian klien dan keluarganya akan termotivasi untuk mengikuti saran perawat. Sebuah komunikasi yang berpusat pada klien adalah teknik pendekatan yang disukai dalam rangka membina hubungan antara klien dan tenaga professional.

Tujuan dari telenursing tidak untuk membentuk diagnosis medis melainkan lebih fokus pada informasi, dukungan, dan meningkatkan pengetahuan. Melalui telenursing, perawat mampu melakukan monitoring, memberikan pendidikan kesehatan, follow up, pengkajian dan pengumpulan data, melakukan intervensi, memberikan dukungan pada keluarga serta perawatan yang inovatif dan kolaborasi. Selain itu dalam penerapan telenursing, perawat melakukan pengkajian lanjutan, perencanaan, intervensi, dan evaluasi terhadap hasil perawatan.

Untuk menerapkan telenursing di Indonesia secara maksimal tentu saja ada beberapa hal yang harus dipersiapkan antara lain sumber daya manusia kesehatan yang mengerti teknologi, sarana dan prasarana teknologi informasi yang memadai, tersedianya panduan dan standar praktek, adanya kode etik dan suatu badan yang akan mengatur praktek telenursing dengan profesi kesehatan yang lain sebagai bagian dari praktek telehealth. Indonesia merupakan negara kepulauan yang sangat sesuai untuk pengaplikasian telenursing sebagai jawaban atas permasalahan kurang meratanya pelayanan kesehatan di wilayah Indonesia, tetapi tentu saja pemerintah dan organisasi profesi harus membuat regulasi yang akan mengatur praktek telenursing, yaitu membuat standar praktek, kode etik, protokol dan panduan telenursing di Indonesia.

\section{UCAPAN TERIMAKASIH}

Terimakasih yang tak terhingga penulis sampaikan kepada Fakultas Ilmu Keperawatan Universitas Indonesia yang telah memfasilitasi dan membekali penulis dengan ilmu pengetahuan sehingga penulis dapat menyelesaikan tinjauan literatur ini

\section{DAFTAR PUSTAKA}

Asiri, H., \& Househ, M. (2016). The Impact of Telenursing on Nursing Practice and Education: A Systematic Literature Review, 105-109.

https://doi.org/10.3233/978-161499-664-4-105

George, I. S., Baker, J., Karabatsos, G., Hons, M., Brimble, R., Psych, B. A., ... Cullen, M. (2009). How safe is telenursing from home? https://doi.org/10.1016/j.colegn.2 009.05 .002

Ghai, S., \& Kalyan, G. (2013). Telenursing an emerging innovation in health sector. Scientific Session. Retrieved from http://www.indus.org/healthcare/S ecientific Sessions/Dr. Sandhya Ghai -Telenursing.pdf

Glinkowski, W., Pawlowska, K., \& Kozlowska, L. (2013). Telehealth and telenursing perception and knowledge among university students of nursing in Poland. Telemedicine and E-Health, 
19(7),

523-529.

https://doi.org/10.1089/tmj.2012.0 217

Hederberg, M. (2007). (Tele)health promotion in primary healthcare centers - an exploratory study, (19).

Kotsani, K., Antonopoulou, V., Kountouri, A., Grammatiki, M., Rapti, E., Karras, S., ... Kazakos, K. (2018). The role of telenursing in the management of Diabetes Type 1: A randomized controlled trial. International Journal of Nursing Studies, 80(April 2017), 29-35.

https://doi.org/10.1016/j.ijnurstu.2 018.01 .003

I, I. D. A. B., Cristina, K., Araújo, V., Júlia, M., Iv, S., Alemão, H., ... Paulo, T. S. (2016). The communication process in Telenursing: integrative review. Rev Brasileira Enfermagem, 69(4), 718-725. https://doi.org/10.1590/00347167.2016690421i

Jönsson, A. M., \& Willman, A. (2009). Telenursing in home care services experiences of registered nurses. Electronic Journal of Health Informatics, 4(1), 1-7.

McLean, S., Sheikh, A., Cresswell, K., Nurmatov, U., Mukherjee, M., Hemmi, A., \& Pagliari, C. (2013). The impact of telehealthcare on the quality and safety of care: A systematic overview. PLOS ONE, $8(8)$.

https://doi.org/10.1371/journal.po ne. 0071238

Reierson, I. A., Solli, H., \& Bjørk, I. T. (2015). Nursing students' perspectives on telenursing in patient care after simulation. Clinical Simulation in Nursing, 11(4), 244-250. https://doi.org/10.1016/j.ecns.201
5.02 .003

Sanderson, B. A. (2018). The satisfactions of telenursing, 24(7), 32-34.

Schlachta-fairchild, L., Elfrink, V., \& Deickman, A. (n.d.). Chapter 48 . Patient Safety, Telenursing, and Telehealth, (1).

Scotia, C. of R. N. of. (2017). Telenursing, (2000), 1-14.

Sharma, S. B. (2014). Telenursing - a potential resource in the eHealth agenda of India. Journal of the International Society for Telemedicine and eHealth, 2(1), 19-28. Retrieved from http://journals.ukzn.ac.za/index.ph $\mathrm{p} / \mathrm{JISfTeH} /$ article/view/44

Souza-junior, V. D., Amélia, I., Mendes, C., Mazzo, A., \& Godoy, S. (2016). Application of telenursing in nursing practice : an integrative literature review, 29, 254-260.

https://doi.org/10.1016/j.apnr.201 5.05 .005

Sudaryanto, A., \& Purwanti, O. S. (2008). Telehealth dalam pelayanan keperawatan. Seminar Nasional Informatika 2008, (May 2008), 7-10. https://doi.org/10.13140/2.1.4256. 8642

Tavsanli, N. G., Karadakovan, A., \& Saygili, F. (2013). The use of videophone technology (telenursing) in the glycaemic control of diabetic patients: a randomized controlled trial. Journal of Diabetes Research and Clinical Metabolism, 2(1), 1. https://doi.org/10.7243/20500866-2-1 